\title{
Analysis of Non-Professional Investor's Intention to Use XBRL-based Financial Statements Using Social Influence and Effort Expectancy Variables from the Unified Theory of Acceptance and Use of Technology (UTAUT) Model
}

\author{
Satsya Yoga Baswara ${ }^{1}$, Agung Yulianto ${ }^{2}$, Heru Junarto ${ }^{3}$, Ferlia Galuh Puspita ${ }^{4}$ \\ \{satsya.yoga@mail.unnes.ac.id $\left.{ }^{1}\right\}$ \\ Universitas Negeri Semarang, Indonesia ${ }^{1,2,3,4}$
}

\begin{abstract}
This research aimed to examine non-professional investors' behavior who are confronted with presenting financial statements using XBRL. We try to apply two variables from the unified theory of acceptance and use of technology (UTAUT) model (Social Influence and Effort Expectancy). As we know lately, the current global economic condition, the internet, and derivative products, and other products that use computing technology continue to evolve. The one with rapid progress is applying any kind of technology like XBRL in the presentation of financial statements. It is hoped that globally, the XBRL implementation can be mandatory. XBRL can reduce the cost of capital and information asymmetry in the capital market. It is more easily processed or analyzed, and allowing better decision making also enhances financial information transparency. It will enable users to integrate data from various locations in the financial statements. However, there is a problem due to the nature of productivity of information technology itself. Each new technology will require a sufficient amount of time to be implemented effectively and certainly without forgetting the general obstacles that may occur according to each country's character.
\end{abstract}

Keywords: XBRL, Non-professional Investor, Social Influences, Effort Expectancy

\section{Introduction}

In the current global economic period, when using the internet and derivative products and other products that use computing technology continues to evolve increasingly sophisticated. One that continues to experience rapid progress is applying XBRL (eXtensible Business Reporting Language) to present financial statements [1]. The implementation of XBRL itself globally is mandatory or voluntary. Initially, the countries included in the compulsory jurisdiction of XBRL included Denmark, Japan, Singapore, South Korea, and the United States of America, and included in the voluntary administration include Australia, Germany, and the Netherlands. However, a number of these countries whose applications are mandatory to continue to grow over time. XBRL can continue to grow since it was first introduced because, following Arnold [2], the use of XBRL will allow the use of standard marking systems for quantitative and qualitative information. This can improve the reliability and efficiency of 
financial and non-financial reporting while making it easier for shareholders to extract all the necessary information [3].

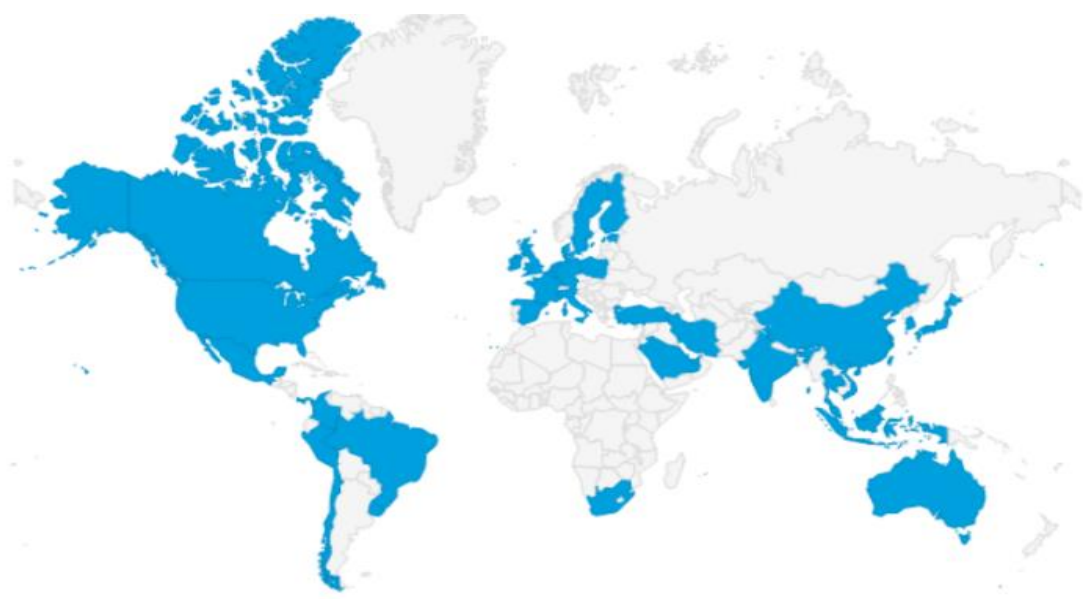

Fig. 1. Jurisdiction of XBRL 2020 (blue color) [4].

Yon et al. [5] also argues that the use of XBRL can reduce capital costs and information asymmetry in the capital market. Besides, the XBRL report's information is easily read by computers, so it is more easily processed or analyzed [6]. These conditions allow users of financial statements to do many things, from viewing to analyzing data [7][8][9]. Systematicity is that XBRL has unique tags that define labels and provide relevant information for each line item in the financial statements. This allows users to understand each line item from the financial statements [10][11]. Apart from that, XBRL also will enable users to easily comparing company performance based on periods, and allowing better decision making [12][13]. Furthermore, XBRL will allow users to obtain relevant information more efficiently for decision-making purposes [12].

Transparency of financial information is also enhanced by XBRL because the data is clearly marked and well documented and allows users to integrate information from various locations in financial statements [14]. XBRL also provides information to be retrieved at the right time. These features specifically only exist in the XBRL reporting format, not in the nonXBRL reporting format. All conveniences offered by XBRL certainly are also inevitable from problems, because following Liu et al. [13], the application of XBRL can be hampered due to the nature of productivity of information technology itself, where each new technology will require a sufficient amount of time to be implemented effectively and certainly without forgetting the general obstacles that might occur according to the character in each country that applies. The application of XBRL itself in Indonesia became mandatory in November 2015. The level of XBRL usage in Indonesia continues to increase every year. Following Indonesia Stock Exchange [15], the level of use of XBRL for quarterly financial statements in 2019 reached $95 \%$, compared to $78 \%$ when it was first applied in 2015. In February 2020, IDX released a new XBRL taxonomy to replace Indonesia's XBRL taxonomy in 2014. This proves that BEI is very committed to implementing XBRL to provide full services for all its users.

Why IDX implements XBRL because BEI wants to reach different types of investors from existing ones, the kind of investor referred to here is non-professional investors. The description 
of the non-professional investors themselves is the type of investor who has risk avoidance preference or laypeople who have not been exposed to knowledge of the capital market. In this study, the authors want to examine the behavior of non-professional investors. The latter are confronted with presenting financial statements that will be hypothesized that the sample will get financial information marked XBRL to be more relevant, understandable, and comparable to their decision making compared to the traditional reporting format. The originality of this research is, the author tries to apply two variables from the unified theory of acceptance and use of technology (UTAUT) model, which is adjusted to the main objective of this study, which aims to examine the intention of XBRL use behavior on non-professional investors.

\section{1 eXtensible Business Reporting Language (XBRL)}

The understanding of XBRL itself, following Lai [16], is an international financial reporting code and XML (eXtensible Markup Language) application used to tag financial and non-financial data, making it easier to analyze various advanced needs. The XBRL concept first appeared in 1998 by Charles Hoffman, with XBRL International, Inc., founded in 2000. The primary purpose of XBRL, following Cohen [17], is to establish global reporting specifications, making it easier for authorities, companies, and investors to collect, exchange and analyze information, and overcome the problems of various approaches used in multiple countries.


Fig. 2. eXtensible Business Reporting Language [15].

XBRL was explicitly created to communicate business information between businesses and financial information users, such as analysts, investors, and regulators, by presenting a general electronic format for business reporting.

XBRL is not a software or application brand that will replace the existing system. XBRL is not a new accounting standard, and its application does not require changes in accounting standards that have been applied in a country. XBRL will not change the XBRL reporting format is not an accounting chart and is not a tool for translating account charts.

\subsection{Unified Theory of Acceptance and Use of Technology (UTAUT)}

UTAUT is one of the integrated technology acceptance models, resulting from modeling developed by Venkatesh et al. [18]. The UTAUT model combines several elements synthesized from several existing technology acceptance theories. These theories are the theory of reasoned action (TRA), technology acceptance model (TAM), motivational model (MM), the theory of planned behavior (TPB), combined TAM and TPB, a model of PC utilization (MPTU), innovation diffusion theory (IDT), and social cognitive theory (SCT). Following Venkatesh et al. [18], the UTAUT model has been shown to have a higher chance of success than other technology acceptance theories because it can explain up to $70 \%$ of user variants. A significant 
finding from the UTAUT model is the production of four (4) constructs/dimensions that can be used as significant direct determinants of behavioral intention or use behavior in one or more of each model. These constructs/dimensions include:

1. Performance expectancy,

2. Effort expectancy,

3. Social influence,

4. Facilitating conditions.

In addition to the four dimensions, the UTAUT model also has four variables that can be positioned as moderating: gender, age, voluntariness, and user experience.

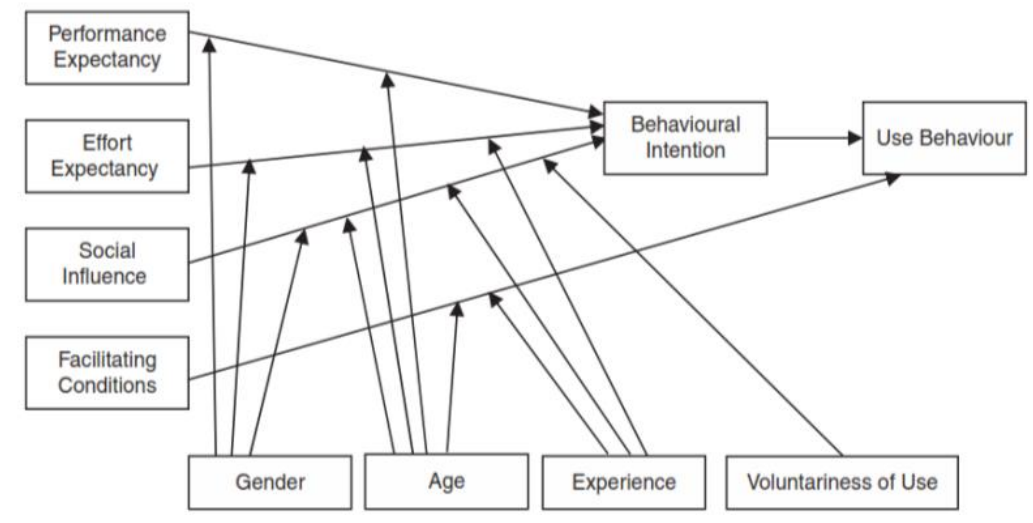

Fig. 3. Unified theory of acceptance and use of technology [18].

For this research, not all dimensions in the UTAUT model are used. Specifically, there are two (2) dimensions/constructs, i.e., Effort expectancy (EE) and Social Influence (SI). Only those two variables are used because the target population used is Mostly the millennial generation so that the things chosen are the closest to the most likely issue or concern for the millennial generation. The moderating variables used are those that are attached to each dimension/construct. They are gender, age, and experience.

Based on the above description, the research drawings can be made as follows:

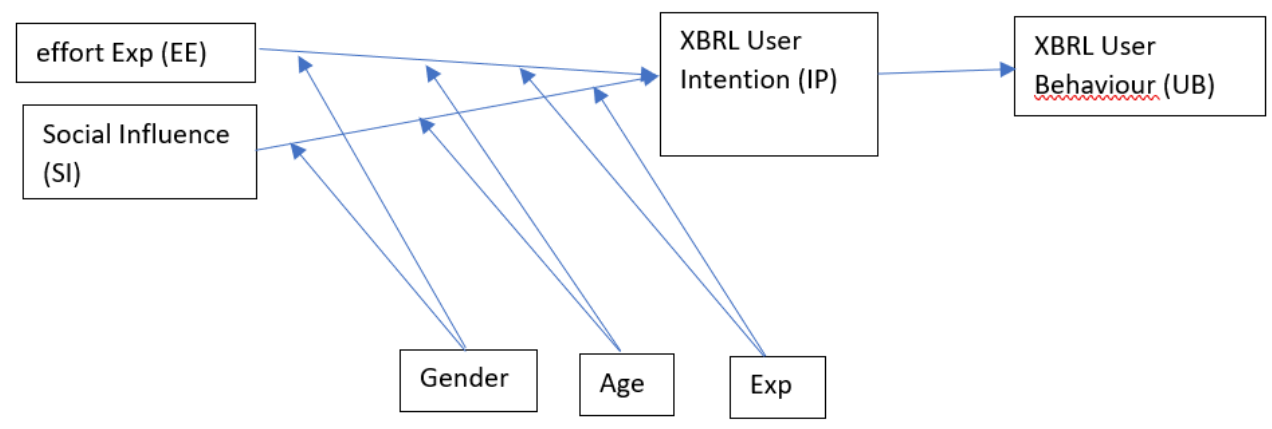

Fig. 4. Research drawing. 


\section{Conceptual Framework and Hypothesis Development}

Following Venkatesh et al. [9], the UTAUT Model has proven its validity can be used in research in communication and technology to investigate individuals' readiness to use technology/information systems in various contexts. Based on the description above.

\subsection{Effort Expectancy (EE)}

Business expectations are defined as the level of ease associated with using the system. Three constructs of the existing model capture the concept of business expectation: perceived ease of use (TAM/TAM2), complexity (MPCU), and ease of use [19].

$\mathrm{H} 1$ : The positive influence of business expectations on non-professional investors' intention to use XBRL is moderated by gender.

$\mathrm{H} 2$ : Positive influence of business expectations on the intention of non-professional investors to use XBRL is moderated by age.

H3: The positive influence of business expectations on the intention of non-professional investors to use XBRL is moderated by experience.

\subsection{Social Influence $(\mathrm{SI})$}

Social influence is defined as the extent to which an individual considers others to be important so that they believe he must use a new system/technology. As a direct determinant of intention behavior, social influence is represented as a subjective norm [20].

H4: Social influence positively impacts non-professional investors' intention to use XBRL with gender as a moderator.

H5: Social influence has a positive influence on the intention of non-professional investors to use XBRL with age as a moderator

H6: Social influence has a positive impact on the intention of non-professional investors to use XBRL with experience as a moderator

\subsection{Individual Intentions to Use Technology}

Individual intention behavior is explained using the TA model. The use of a technology or system should be determined by the user's attitude, who, in time, will determine whether the system or technology is useful or easy to use or not [21]. Normative pressure or subjective norms become influential because an individual may be exposed to outside influences, such as other people or their environment [9]. The UTAUT model explores how individuals accept and use technology in their environment, using four dimensions: individual performance expectations, business expectations, social influence, and facility conditions [9]. Based on the above arguments, the following hypotheses are formulated

H7: The intention of non-professional investor behavior influences the use of XBRL. (with effort expectancy and social influence as variable construct 


\section{Research Method}

\subsection{Research Design}

This research is a quantitative research method, namely, a study that emphasizes its analysis of numerical data or numbers obtained for statistical purposes and testing hypotheses to get the significance of the relationship between the variables studied. The analytical tool used is the PLS Warp. The flowchart for this research is as follows:

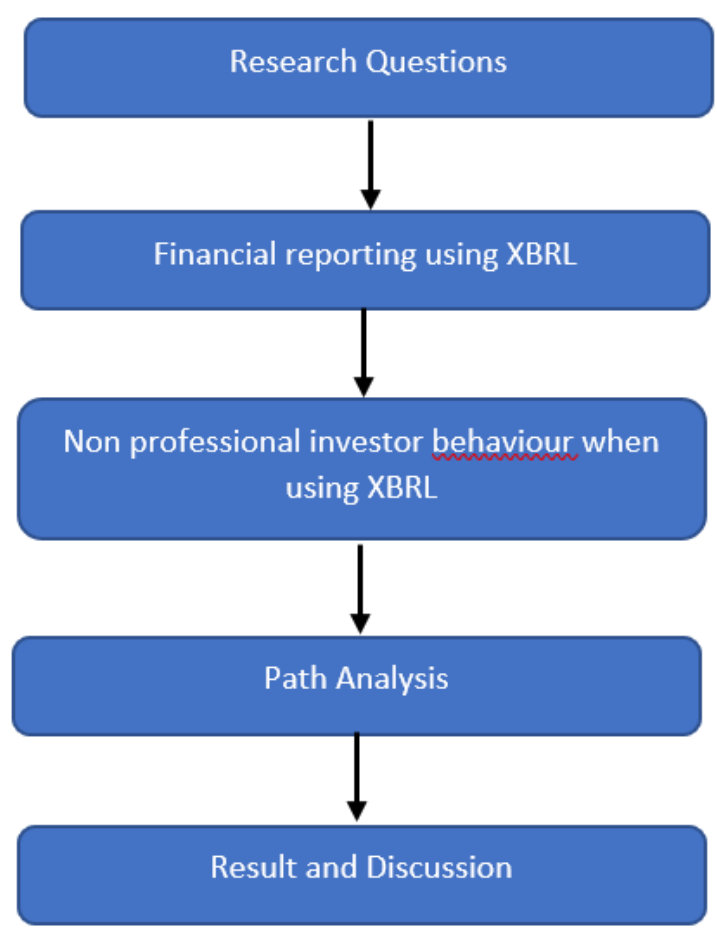

Fig. 5. Research Design.

\subsection{Population and Research Samples}

This study's population is non-professional investors, which means investors are not or have never been but only a little knowledgeable about investment science. Using a purposive sampling technique, several requirements were determined to be included in the nonprofessional classification of investors. The sample used can be college students from the Faculty of Economics, UNNES, or the general public. We defined the students' classification as there should already minimum at second semesters.

\subsection{Research Variable}

The research variables consist of independent variables, moderation variables, and dependent variables. The following is an operational explanation of each variable. 


\begin{tabular}{|c|c|c|c|}
\hline No & Variable & Operational definition & Indicators \\
\hline \multirow{3}{*}{1} & Variable Independent & & \\
\hline & Effort expectancy & $\begin{array}{l}\text { Individuals feel that the } \\
\text { technology (XBRL) has a } \\
\text { level of effort to be used }\end{array}$ & $\begin{array}{l}\text { 1. Complexity } \\
\text { 2. Perceived of use } \\
\text { 3. Easy to use }\end{array}$ \\
\hline & Social influence & $\begin{array}{l}\text { Individuals believe that } \\
\text { external social values can } \\
\text { support the acceptance and } \\
\text { use of XBRL }\end{array}$ & $\begin{array}{l}\text { 1. Subjective norm } \\
\text { 2. Social factors } \\
\text { 3. Image }\end{array}$ \\
\hline \multirow{4}{*}{2} & Variable Moderating & & \\
\hline & Gender & $\begin{array}{l}\text { Individual gender of XBRL } \\
\text { user }\end{array}$ & Male and female \\
\hline & Age & Age of each XBRL user & Age \\
\hline & Experience & $\begin{array}{l}\text { Knowledge and skills } \\
\text { possessed by XBRL users }\end{array}$ & $\begin{array}{l}\text { Experience using } \\
\text { financial information }\end{array}$ \\
\hline \multirow[b]{2}{*}{3} & Variable Intervening & & \\
\hline & $\begin{array}{l}\text { The intention of non- } \\
\text { professional investor } \\
\text { behavior }\end{array}$ & $\begin{array}{l}\text { Trends in the behavior of an } \\
\text { individual, non-professional } \\
\text { investors using XBRL }\end{array}$ & $\begin{array}{l}\text { 1. Likely to continue } \\
\text { 2. Habit } \\
\text { 3. Happy to use }\end{array}$ \\
\hline \multirow[b]{2}{*}{4} & Variable Dependent & & \\
\hline & Use Behavior XBRL & $\begin{array}{l}\text { Individual, non-professional } \\
\text { investors accept and use } \\
\text { technology in XBRL }\end{array}$ & $\begin{array}{l}\text { 1. Regularly use } \\
\text { 2. Informative } \\
\text { 3. Flexible to use }\end{array}$ \\
\hline
\end{tabular}

\subsection{Data Collection and Analysis Methods}

The data collection method used was a questionnaire. The questionnaire was used to explore XBRL usage behavior. This study uses statistical analysis to answer research questions and test hypotheses by analyzing and testing empirical models, examining the research hypothesis using structural equation modeling (Structural Equation Modeling/SEM) with the WarpPLS approach. The consideration of using a structural analysis model is to explain the relationship and interdependence of research variables. This model was developed as an alternative to situations where the theoretical basis for designing the model is weak or has not been found, and or some indicators do not meet the reflective measurement model, so it is formative. PLS is a powerful analysis method because it does not require many assumptions, and the sample size can be small or large. Besides, PLS can be used as a confirmation of theory (hypothesis testing) can also be used to build relationships that do not yet have a theoretical basis or to test propositions [22].

\section{Result and Discussion}

The Sem image model to test the Moderation Hypothesis produces the following image. 


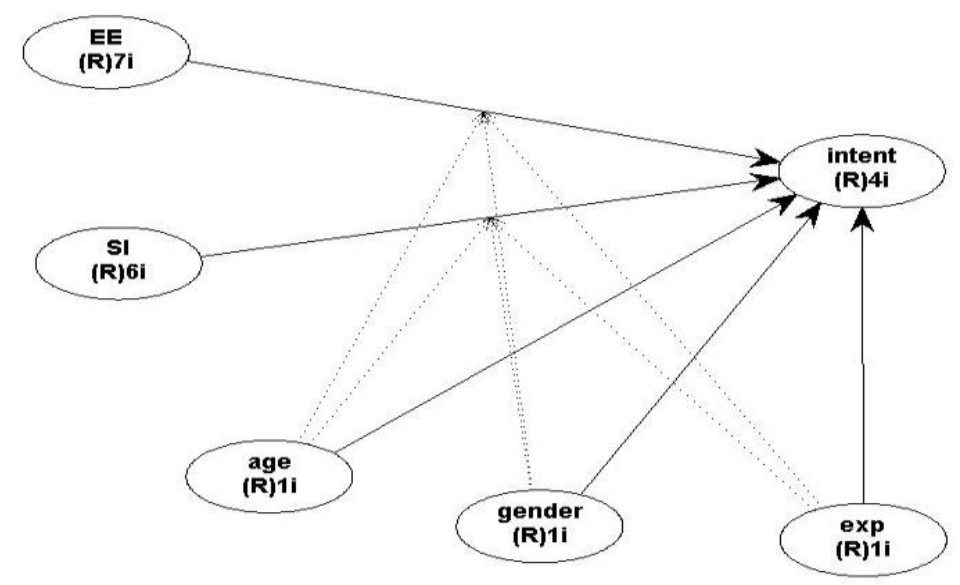

Fig. 6. Moderation hypothesis produces.

The construct used is a reflective construct with each indicator attached because what is tested in hypotheses 1 through 6 is the effect of moderation. After running using the Warp PLS software, the PLS image is produced as follows.

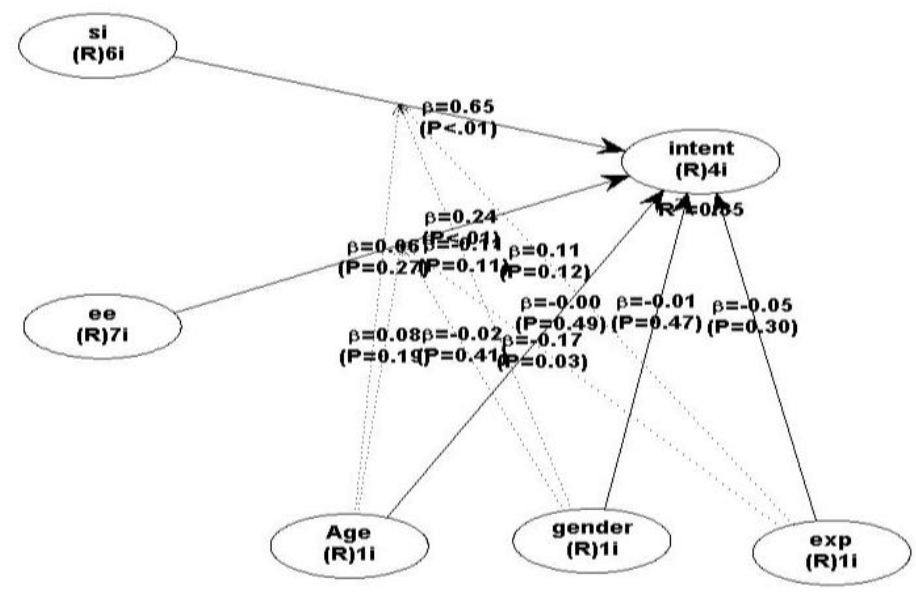

Fig. 7. Warp PLS software.

The picture above can be drawn to the results associated with several hypotheses related to the moderation relationship. That SI (social influence) in its direct connection to intent (intention to use XBRL) is definite; this is evidenced by the amount of P-Value, which is $<0.05$. also obtained results that EE (effort expectancy) indirect relationships with intent (intention to use XBRL) positively affects. This can be proven by the results of the P-value $<0.05$. Whereas the moderation relationship can be explained as follows in the case of $\mathrm{H} 1$, business expectations did positively affect non-professional investors' intention to use XBRL. Still, in testing, it was found that the relationship between sex and intent was not significant. 
$\mathrm{P}$ Value $>0.05$, gender as a moderating variable between business expectations influence on intent is a potential moderation relationship. This also happens to $\mathrm{H} 2$, which, as already known about $\mathrm{EE}$, has a positive effect on intention, but age is used as a moderating variable. $\mathrm{P}$ values are also > 0,05 , so the relationship is also potential moderation.

In $\mathrm{H} 3$, the same case also occurs because $\mathrm{P}$ value $>0,05$, then the experience variable's moderation relationship is a potential moderation relationship. As for $\mathrm{H} 4$, social influence positively affects non-professional investors' intention to use XBRL, and the relationship between sex and intent is not significant. P Value> 0.05, gender as a moderating variable between the influence of social influence on intent is the potential moderation relationship. This also happens to H5, which, as has been known that SI has a positive effect on intention, but the age used as moderating variable $\mathrm{P}$ values are also $>0.05$.

The relationship is a type of potential moderation. Finally, on H6, because of $\mathrm{P}$ value> 0.05 , the moderating relationship of the experience variable to the relationship of social influence to intention to use XBRL is a potential moderation relationship.

For testing H7, the technique used is slightly different, although still using the Warp PLS 5.0 software. Why is it different due to the nature of the relationship in $\mathrm{H} 7$ itself? The association is a second-order construct relationship that seeks to explain how the influence of the relationship between non-professional investors intends to use XBRL with XBRL usage behavior. So here, Social influences and effort expectancy become dimensions/constructs of intention variables. SI and EE are formed as reflective variables, while intent and use behavior are used as formative variables. Tests carried out are two (2) times. The first is to test the outer model, while the second is the inner model. Testing the outer model has obtained the following results.

The results of measurements and readings of the outer model are two things: construct validity, in which there is convergent validity and discriminant validity. Second is Construct reliability is measured by Cronbach Alpha and composite reliabilities. Further explanation is as follows:

1. Convergent validity with the expected score is \pm 0.7 and has a P-value $<0.05$. For both variables, EE and SI have fulfilled both of these requirements.

2. Correlation among latent Variants (VAL's) for the EE and SI reflective variables must be higher than the score per column, i.e., the scores are 0.727 and 0.618

3. Construct reliability. To be able to find construct reliability is to look at the value of Cronbach's alpha (CA) and composite reliabilities $(\mathrm{CR})$ with a score of $>0.70$. The results for $\mathrm{CR}$ and $\mathrm{CA}$ for the $\mathrm{EE}$ and $\mathrm{SI}$ variables are for $\mathrm{EE}, \mathrm{CA}=0.850 \mathrm{CR}=0.886$ and for SI, $\mathrm{CA}=0.904 \mathrm{CR}=0.927$.

Based on these results, the EE and SI variables have met the construct reliability. With the three points above already fulfilled, Effort expectancy (EE) and Social Influence (SI) have met the requirements to become REFLECTIVE variables. Furthermore, after measuring the outer model, then what is measured next is the inner model or the so-called structural model. This model is a continuation of the outer model that clearly illustrates the relationship between nonprofessional investors' intention to use XBRL to use XBRL behavior with EE and SI as the second-order construct dimension of the non-professional investor's intention to use XBRL. The resulting model is as follows. 


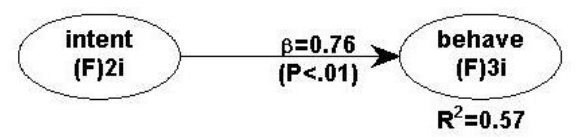

Fig. 8. XBRL model.

The picture above can be read as follows. When viewed from the weight indicator, to be a variable that meets the formative construction concept, $\mathrm{P}$ Values must be $<0.05$. As an illustration, the two variables, intent and behavior, have different indicators for each variable. For the intent, the variable has two indicators, namely LvEE and LvSI. Both of these indicators have a $\mathrm{P}$-value of $\mathrm{P}<0.001$, which is compliant because $<0.05$. Simultaneously, the behavior variable has three indicators, namely, UB1, UB2, and UB3.

Every indicator has a P-value of $<0.001$, which is according to because it is $<0.05$. The next is the multicollinearity test. All of the existing indicators are according to the requirements. Because of the VIF value <10. Each indicator has the following VIF value: $\mathrm{LvEE}=1.841 ; \mathrm{LvSI}$ $=1,841 ; \mathrm{UB} 1=4.959 ; \mathrm{UB} 2=5,323 ; \mathrm{UB} 3=4.983$. The latest reading to answer the 7th $/ 7$ th hypothesis is path coefficients analysis or path coefficient analysis of the relationship between variables of non-professional investors' intention to use XBRL with behavioral variables using XBRL. As a second-order construct model, the intention variable in the relationship affects the behavior of using; the intention variable has two (2) dimensions, namely Effort Expectancy (EE) and Social influences (SI). The path coefficient analysis results are an effect of 0.755 and a significant positive with a P-value $<0.001$.

\section{Conclusion}

From the results and discussion above, it can be concluded that the use of age, sex, and experience as a moderating variable in the relationship between Effort expectancy and intention to use and social influences to use is in the form of potential moderation, as for the submission of social influences and effort expectancy as a second-order construct of the intention of nonprofessional investors to use XBRL about behavior using XBRL, positive and significant results are obtained. Further research can use other variables outside the UTAUT model.

\section{References}

[1] Ernst and Young, "What is XBRL?," EY, 2014. [Online]. Available: www.ey.com/US/en/Issues/Governance-and-reporting/XBRL/Assurance-XBRL-Web-EnabledBusiness-Reporting.

[2] V. Arnold, J. C. Bedard, J. R. Phillips, and S. G. Sutton, "The impact of tagging qualitative financial information on investor decision making: Implications for XBRL," Int. J. Account. Inf. 
Syst., vol. 13, no. 1, pp. 2-20, 2012.

[3] E. Blankespoor, B. P. Miller, and H. D. White, "Initial evidence on the market impact of the XBRL mandate," Rev. Account. Stud., vol. 19, no. 4, pp. 1468-1503, 2014.

[4] A. Krumm, "XBRL: International Best Practice, Global Reporting, and Your Business," Cortell Corporate Performance Management, 2018. [Online]. Available: http://www.cortell.co.za/xbrlinternational-best-practice-global-reporting-business/.

[5] H. Yoon, H. Zo, and A. P. Ciganek, "Does XBRL adoption reduce information asymmetry?," J. Bus. Res., vol. 64, no. 2, pp. 157-163, 2011.

[6] J. L. Birt, K. Muthusamy, and P. Bir, "XBRL and the qualitative characteristics of useful financial information," Account. Res. J., 2017.

[7] J. Efendi, J. D. Park, and L. M. Smith, "Do XBRL filings enhance informational efficiency? Early evidence from post-earnings announcement drift," J. Bus. Res., vol. 67, no. 6, pp. 1099-1105, 2014.

[8] T. S. Harris and S. G. Morsfield, "An evaluation of the current state and future of XBRL and interactive data for investors and analysts," 2012.

[9] V. Venkatesh, J. Y. L. Thong, and X. Xu, "Venkatesh_Thong_Xu_MISQ_forthcoming (Gender Age Experience)," MIS Q., vol. 36, no. 1, pp. 157-178, 2012.

[10] E. K. Ghani, F. Laswad, and S. Tooley, "Functional fixation: Experimental evidence on the presentation of financial information through different digital formats," Br. Account. Rev., vol. 43, no. 3, pp. 186-199, 2011.

[11] M. A. Vasarhelyi, D. Y. Chan, and J. P. Krahel, "Consequences of XBRL standardization on financial statement data," J. Inf. Syst., vol. 26, no. 1, pp. 155-167, 2012.

[12] A. A. Baldwin and B. S. Trinkle, "The impact of XBRL: A Delphi investigation," Int. J. Digit. Account. Res., vol. 11, no. 1, pp. 1-24, 2011.

[13] C. Liu, X. R. Luo, C. L. Sia, G. O'farrell, and H. H. Teo, "The impact of XBRL adoption in PR China," Decis. Support Syst., vol. 59, pp. 242-249, 2014.

[14] M. Alles and M. Piechocki, "Will XBRL improve corporate governance?: A framework for enhancing governance decision making using interactive data," Int. J. Account. Inf. Syst., vol. 13, no. 2, pp. 91-108, 2012.

[15] Bursa Efek Indonesia, "Mengenai XBRL," Bursa Efek Indonesia. [Online]. Available: https://www.idx.co.id/perusahaan-tercatat/xbrl/.

[16] S.-C. Lai, Y.-S. Lin, Y.-H. Lin, and H.-W. Huang, "XBRL adoption and cost of debt," Int. J. Account. Inf. Manag., 2015.

[17] E. E. Cohen, "XBRL's Global Ledger Framework: Exploring the standardised missing link to ERP integration,” Int. J. Discl. Gov., vol. 6, no. 3, pp. 188-206, 2009.

[18] V. Venkatesh, M. G. Morris, G. B. Davis, and F. D. Davis, "User acceptance of information technology: Toward a unified view," MIS Q., pp. 425-478, 2003.

[19] C. R. Plouffe, J. S. Hulland, and M. Vandenbosch, "Richness versus parsimony in modeling technology adoption decisions - understanding merchant adoption of a smart card-based payment system," Inf. Syst. Res., vol. 12, no. 2, pp. 208-222, 2001.

[20] R. L. Thompson, C. A. Higgins, and J. M. Howell, "Personal computing: Toward a conceptual model of utilization," MIS Q., pp. 125-143, 1991.

[21] F. D. Davis, R. P. Bagozzi, and P. R. Warshaw, "User acceptance of computer technology: a comparison of two theoretical models," Manage. Sci., vol. 35, no. 8, pp. 982-1003, 1989.

[22] M. Sholihin and D. Ratmono, Analisis SEM-PLS dengan WarpPLS 7.0 untuk Hubungan Nonlinier dalam Penelitian Sosial dan Bisnis. Penerbit Andi, 2021. 